\title{
Agricultural irrigation in Hungary, with special regards to the water resources levy and agricultural water supply fee
}

\begin{abstract}
The price of the agricultural irrigation is determined by the water resources levy and agricultural water supply fee, which are regulated under Article 15/A(1) and Article 15/F(1) of the Act LVII of 1995 on Water Management. A kind of dualism concerning the price of the irrigation can be observed in Hungary. On the one hand, the necessity to irrigate has to be reflected in the price due to the negative impacts of drought on crop production, although irrigation scores low on the hierarchy of water uses. On the other hand, the price must also express the value of water as an irreplaceable natural resource with limited renewable capacity. Based on the analysis of the said provisions, it can be concluded that though allowing derogations from paying for the agricultural irrigation can be justified in many cases, concerns can be raised regarding their uniform application without involving discretion regardless, among others factors, of the differences in the economic situation of the farmers.
\end{abstract}

Keywords: agriculture, irrigation, water resources levy, agricultural water supply fee, water

\begin{abstract}
ABSZTRAKT
A vízkészletjárulék és a mezőgazdasági vízszolgáltatási dij alapján határozható meg az öntözés ára. Ezekről a vízgazdálkodásról szóló, 1995. évi LVII. törvény 15/A. (1) és a 15/F. (1) szakaszai rendelkeznek. Az öntözésre vonatkozó magyar szabályozásnak kettös követelménynek kell eleget tennie. Egyfelöl, az aszály növénytermesztésre gyakorolt negatív hatása miatt az öntözés szükségességének és fontosságának meg kell jelennie az árra vonatkozó szabályokban (annak ellenére, hogy az öntözés az utolsó elötti helyen áll a vízkielégítési sorrendben). Másfelöl, az árnak tükröznie kell a víz értékét, nevezetesen, hogy a víz mással nem helyettesithető és feltételesen megújuló természeti erőforrás. A fent emlitett rendelkezések elemzését követően az a következtetés vonható le, hogy noha sok esetben igazolható az öntözéshez kapcsolódó járulék, illetve dij megfizetése alóli mentesség biztositása, ugyanakkor ezeknek a mérlegelés nélküli, egységes alkalmazása, pl. a vízhasználók gazdasági erejére való tekintet nélkül, nem indokolt.
\end{abstract}

Kulcsszavak: mezőgazdaság, öntözés, vízkészlet-járulék, mezőgazdasági vízszolgáltatási dijj, víz

In Hungary, 28 out of 100 years are dry and droughty, but a successive series of droughty years are also common. In addition, in some years, such as in 2000 , drought, inland inundation, flood and frost damage occurred together. ${ }^{1}$ The damage

${ }^{1}$ A globális klímaváltozás: hazai hatások és válaszok [Global climate change: national impacts and answers]. KvVM-MTA „VAHAVA projekt” (elözetes összefoglalás). Budapest, 2005, http://netrix.mta.nsd.sztaki.hu/fileadmin/2005/09/vahava0915.pdf [hereinafter: VAHAVA], 19. (31. 12. 2019).

* Dr. Ágnes Bujdos, research fellow, University of Debrecen Faculty of Law, bujdos.agnes@law.unideb.hu. The research was financed by the Higher Education Institutional Excellence Programme (NKFIH-1150-6/2019) of the Ministry of Innovation and Technology in Hungary, within the framework of the $4^{\text {th }}$ thematic programme of the University of Debrecen. 
caused by persistent drought affects degraded soils in their physical and biological state, as well as soils with low nutrient level much more severely. Conversely, the good physical and biological condition of soils improves the drought tolerance of the field. ${ }^{2}$ Most recently, in 2018, under the national agricultural damage-mitigation scheme, farmers were paid HUF 7.6 billion as compensation for the negative impact of weather (primarily drought, inland inundation and hail damage) on agriculture.$^{3}$ In addition, in October 2019, as part of the agricultural damage-mitigation scheme, the minister in charge of agriculture published his communication on drought in which it was acknowledged that in Hungary, during the 2019 compensation year, there was a drought throughout the country. ${ }^{4}$

As a response to the drought in agriculture, Government Decree 1744/2017 (X. 17.) on the formulation of the Irrigation Development Strategy declares that the "Government considers the issue of spreading and rational development of irrigated cultivation, and the protection and utilization of water resources to be a state task, and therefore agrees with the necessity of formulating the Irrigation Development Strategy." 5

The current contribution wishes to examine a kind of dualism concerning the price of the agricultural irrigation. On the one hand, the necessity to irrigate has to be reflected in the price of water for irrigation due to the negative impacts of drought on crop production in Hungary. On the other hand, the price must also express the value of water as an irreplaceable natural resource with limited renewable capacity. The price of the agricultural irrigation is determined by the water resources levy and agricultural water supply fee, which are regulated under Article 15/A(1) and Article 15/F(1) of the Act LVII of 1995 on Water Management (hereinafter: Water Management Act). Before the thorough analysis of these provisions, first, Hungary's climate and water resources will be introduced, followed by the examination of the relationship between agriculture and irrigation, with special regards to Hungary. Then, the order of satisfaction of water needs, with special emphasis on irrigation will be discussed. Finally, some conclusions will be drawn.

\section{Hungary's climate and its water resources}

Freshwater is a precondition of life for which there is no alternative. Therefore, water is often referred to as "liquid gold" 6 or the "lifeblood of the planet." These phrases reflect not only its limited availability as no more than 0.7 per cent is available as freshwater $(0.66$ per cent of which is groundwater and just 0.03 per cent is available

\footnotetext{
2 VAHAVA: op. cit., 29.

${ }^{3}$ https://www.nak.hu/tajekoztatasi-szolgaltatas/mezogazdasagi-termeles/101149-kozel-800-milliard-forinttamogatas-segitette-tavaly-a-gazdakat (31. 12. 2019).

${ }^{4}$ https://www.kormany.hu/hu/foldmuvelesugyi-miniszterium/mezogazdasagert-felelos-allamtitkarsag/hirek/ karenyhito-juttatas-igenyelheto-aszalykar-utan (31. 12. 2019).

5 This strategy has not been published yet.

${ }^{6}$ Neill, Frank: The law around New Zealand's 'liquid gold'. LawTalk, Issue 801, 2012, 6.

7 Climate Change Adaptation: The Pivotal Role of Water. UNWater Policy Brief, 2010, https://www.unwater.org/ app/uploads/2017/05/unw_ccpol_web.pdf, 2. (31. 12. 2019).
} 
as surface water in rivers, lakes and streams), ${ }^{8}$ but the growing competition for water between the four main water consumption sectors, namely households, agriculture, energy production and industry. ${ }^{9}$

Although water is generally considered to be a local issue, it is also a global concern interlinked with many subjects, among others, overexploitation of water resources, food security and climate change..$^{10}$ These concerns are deeply embedded in the European Commission's Communication on Addressing the challenge of water scarcity and droughts in the European Union, in which it is predicted that "Population growth and the competing needs of water users will result in an increase of global water demand of $35-60 \%$ by 2025 . This could double by 2050 . These trends will be exacerbated by climate change, with serious implications for food security." ${ }^{\prime 11}$ As also stated in the said Communication, "water scarcity and droughts have now emerged as a major challenge - and climate change is expected to make matters worse."12

Moving onto Hungary's water resources it can be stated that thanks to its location 95 per cent of Hungary's waters come from beyond its borders and approximately 90 per cent of these waters leave Hungary at the southern part of the country. ${ }^{13}$ Hungary's water network, which includes lakes, brooks and canals, constitutes some 90000 km. ${ }^{14}$ Nevertheless, soil can be deemed to be Hungary's largest reservoir. ${ }^{15}$ The country's yearly precipitation is $500-900 \mathrm{~mm}$. Its natural water balance is positive since the total precipitation is 55707 million $\mathrm{m}^{3}$, whereas the evapotranspiration is 48174 million $\mathrm{m}^{3}{ }^{16}$ That means that its total precipitation per year exceeds its yearly evapotranspiration. No significant change in the annual amount of precipitation can be predicted; however, its distribution between the four seasons is likely to be altered due to climate change. What seems certain is that summer rainfall will decrease by 5 per cent in the coming decades and by 20 per cent by the end of the century ${ }^{17}$ In terms of precipitation, on the one hand, it is noteworthy that summer precipitation has become more intense and thus less useful. On the other hand,

${ }^{8}$ De, Anil Kumar-De, Arnab Kumar: Environmental Engineering. New Age International Ltd, New Delhi, 2009, 66-67. Interestingly, see further: Brown Weiss, Edith: International Law for a Water-Scarce World, Martinus Nijhoff Publishers, Leiden, Boston, 2013.

${ }^{9}$ World Water Development Report 4 - Background Information Brief. www.unesco.org/new/fileadmin/MULTIMEDIA/HQ/SC/pdf/WWDR4 Background Briefing Note_ENG.pdf (31. 12. 2019).

${ }^{10}$ Communication from the Commission to the European Parliament, the Council, the European Economic and Social Committee and the Committee of the Regions: A Blueprint to Safeguard Europe's Water Resources. $\mathrm{COM} / 2012 / 0673$ final, 18.

${ }^{11}$ Communication from the Commission to the European Parliament and the Council: Addressing the challenge of water scarcity and droughts in the European Union. COM(2007) 414 final, 18.

12 Ibid., 2.

${ }^{13}$ Bruhács, János: Nemzetközi Jog II. Különös rész. Dialóg Campus, Budapest, Pécs, 2010, 85.

${ }^{14}$ Nemzeti Vízstratégia (Kvassay Jenő Terv) [National Water Strategy (Jenő Kvassay Plan)], 2017. https://www. kormany.hu/download/6/55/01000/Nemzeti\%20V\%C3\%ADzstrat\%C3\%A9gia.pdf, 27-28. (31. 12. 2019).

15 VAHAVA: op. cit., 19.

${ }^{16}$ Water in Hungary: Status overview for the National Water Programme of the Hungarian Academy of Sciences. Budapest, 2017. https://mta.hu/data/dokumentumok/Viztudomanyi\%20Program/Water_in_Hungary_2017_07_20.pdf, 7. (31. 12. 2019).

${ }^{17}$ Második Nemzeti Éghajlatváltozási Stratégia. Melléklet a 23/2018. (X. 31.) OGY határozathoz [Second National Climate Change Strategy. Annex to Parliamentary Resolution 23/2018 (X. 31.)] [hereinafter: NÉS-2], 8. 
the likelihood of drought and water scarcity has increased..$^{18}$ The reduction in the amount of precipitation is likely to be compensated by the increase in autumn and winter rainfall. Additionally, the occurrence of high volume and intense precipitation may be more frequent in the autumn, while the length of the dry periods will increase primarily in the summer. ${ }^{19}$

When it comes to the Hungarian climate, it can be stated that it is characterised primarily by continental climate, accompanied by Atlantic and Mediterranean influences. ${ }^{20}$ Interestingly, under these special climatic conditions, even a slight change or modification in the climate zone may change the dominance of the ruling climate. ${ }^{21}$ Water bodies in Hungary, depending on their type, are sensitive to the spatial and temporal distribution of temperature and precipitation to varying degrees. Research data shows that relatively small changes in precipitation and temperature have a major impact on the water cycle. ${ }^{22}$ Unfortunately, in recent years, Hungary has been affected by extreme weather conditions. This is attributable to climate change and can primarily be observed in the following forms: floods, flash floods and droughts. ${ }^{23}$

\section{The relationship between agriculture and irrigation, with special regards to Hungary}

Rainfed agriculture is the world's predominant agricultural production system, but also hosts the majority of rural poor. ${ }^{24}$ Water availability problems in agriculture hit especially those areas where a high proportion of renewable water resources have already been exploited, or where transboundary resource management cannot be negotiated. ${ }^{25}$ Groundwater use in irrigation is expanding quickly, and almost 40 per cent of the irrigated area is now reliant upon groundwater as either a primary source or in conjunction with surface water. Irrigation has direct benefits in terms of production and incomes. However, irrigation has also been associated with negative impacts for which the costs may at times outweigh the benefits of the production. These impacts may include reduction in environmental flows or changes in downstream access to water.$^{26}$ Furthermore, the more ecologically vulnerable an area is, the less it can tolerate irrigation, as irrigation is considered to be a significant human intervention in the natural processes. ${ }^{27}$

\footnotetext{
18 Ibid., 45.
}

19 Ibid., 8.

20 Water in Hungary: op. cit., 8.

21 VAHAVA: op. cit., 9-10.

${ }^{22}$ Nemzeti Éghajlatváltozási Stratégia 2008-2025. Melléklet a 29/2008. (III. 20.) OGY határozathoz [National Climate Change Strategy 2008-2025. Annex to Parliamentary Resolution 29/2008 (III. 20.)], 139.

${ }^{23}$ Nemzeti Vízstratégia: op. cit., 3.

${ }^{24}$ The State of the World's Land and Water Resources for Food and Agriculture: Managing systems at risk. FAO, Rome-Earthscan, London, 2011. http://www.fao.org/3/a-i1688e.pdf, 3. (31. 12. 2019).

25 Ibid., 5.

${ }^{26}$ Ibid., 4.

${ }^{27}$ Kemény, Gábor-Lámfalusi, Ibolya-Molnár, András (eds.): Az öntözhetőség természeti-gazdasági korlátainak hatása az öntözhető területekre. AKI, Budapest, 2018, 24. 
Agriculture currently uses 11 per cent of the world's land surface for crop production, and accounts for 70 per cent of all water withdrawal from aquifers, streams and lakes. Cultivated land area per person in the low-income countries is less than half that in the high-income countries, and its suitability for agriculture is generally lower. ${ }^{28}$ However, the significance of irrigation can be best illustrated with the relationship between irrigation and food production, namely the "irrigated agriculture represents 20 percent of the total cultivated land, but contributes 40 percent of the total food produced worldwide." ${ }^{29}$ In Europe, on average, agriculture accounts for 44 per cent of total water use. Not to mention this proportion can be as high as 80 per cent in some regions ${ }^{30}$ Nonetheless, "the overall use of water resources can be considered sustainable in the long-term in most of Europe." ${ }^{31}$ The high proportion of water abstraction for irrigation raises the question as to what kind of factors determine the irrigation water requirements of crops. These requirements are determined by the crop water requirement, as well as by the water naturally available to the crops including inter alia effective precipitation and soil moisture. Accordingly, irrigation water requirement of crops can be calculated with an awareness of climatic conditions and the physiological processes at plant level. Regrettably, water withdrawal for irrigation often far exceeds the irrigation water requirement that is attributable to significant losses in distribution and application. ${ }^{32}$

Turning our attention to Hungary, it is worth noting that the vast majority of the lands $\left(74000 \mathrm{~km}^{2}\right.$ out of $\left.93000 \mathrm{~km}^{2}\right)$ are used for agricultural purposes, mostly as croplands and pastures, covering 58.7 per cent and 10.3 per cent of Hungary's territory. ${ }^{33}$

In 2013, the agriculture sector accounted for merely 6 per cent of all water abstractions in Hungary, which might seem insignificant compared with the 77 per cent share of energy industry (only for cooling purposes), however, agricultural irrigation is by far the most water demanding sector because plants almost completely use or evaporate the irrigated water. ${ }^{34}$ According to the revised National River Basin Management Plan adopted in 2015, 1-2 per cent of the Hungarian agricultural lands are irrigated depending on the weather conditions, whereas the proportion of the irrigable land is 3.3 per cent. ${ }^{35}$ It is also worth referring to the data of the Eurostat concerning the share (in percentage) of irrigable and irrigated areas in utilised agricultural area by NUTS 2 regions in Hungary. In this context, irrigable area is defined as the "area which is equipped for irrigation", whereas under irrigated area "the actual

${ }^{28}$ The State of the World's Land and Water Resources for Food and Agriculture: op. cit., 3.

${ }^{29}$ www.worldbank.org/en/topic/water-in-agriculture (15. 12. 2019).

${ }^{30} \mathrm{https} / / /$ ec.europa.eu/info/news/future-cap-sustainability-water-source_en (17. 12. 2019).

31 https://ec.europa.eu/eurostat/statistics-explained/index.php?title=Water_statistics\#Water_as_a_resource (17. 12. 2019).

32 www.fao.org/nr/water/aquastat/water_use_agr/index.stm (14. 12. 2019).

${ }^{33}$ Water in Hungary: op. cit., 9.

34 Ibid., 29.

35 Magyarország felülvizsgált, 2015. évi Vízgyűjtő-gazdálkodási Terve [Revised National River Basin Management Plan of 2015], 268. 
amount of land irrigated; based on Farm Structure Survey data" is understood..$^{36}$ This database provides us with data from 2005 to 2016 . When it comes to the irrigable utilised agricultural area, overall, the proportion of this type of area increased, however, some fluctuations could be observed in the said period, that was 3.6 per cent in 2005, 3.3 per cent in 2007, 5.0 per cent in 2010, 5.6 per cent in 2013, and 4.9 per cent in $2016 .{ }^{37}$ As for the irrigated utilised agricultural area, an increasing trend could be concluded starting at 1.8 per cent in 2005 , followed by 2.1 and 2.4 per cent in 2007 and 2010, subsequently, and peaking at 3.0 per cent in 2013, before dropping to 2.6 per cent in $2016 .{ }^{38}$ Taking into consideration the increasing vulnerability to drought and water scarcity as well as the impact of irrigation on crop productivity, it can be concluded that this proportion is indeed very low in the EU. ${ }^{39}$

In terms of the sources of the irrigation water, it can be stated that slightly more than 92 per cent of the water for irrigation come from surface water, approximately 7.5 per cent from groundwater and the remaining water ( 0.3 per cent) from bank filtrate ${ }^{40}$ Irrigation is primarily necessary on the Great Plain, which is characterized by a lower level of precipitation and warmer temperature compared to the rest of the country. That is why this area relies on the utilization of groundwater resources most. ${ }^{41}$ However, when taking a look at the data concerning the productivity of irrigated land and the whole agricultural land, it is conspicuous that there is no sign of that general trend that "irrigated agriculture is, on average, at least twice as productive per unit of land." 42 Surprisingly, data shows that the productivity of the irrigated agricultural land is merely slightly better than the yield of the whole agricultural land. In case of maize, the yield is $9.30 \mathrm{t} / \mathrm{ha}$ for the whole agricultural land and $9.81 \mathrm{t} / \mathrm{ha}$ for the irrigated agricultural land, or regarding the potato similar tendency can be observed, namely $31.97 \mathrm{t} / \mathrm{ha}$ and $33.20 \mathrm{t} / \mathrm{ha}$, for the whole agricultural land and for the irrigated agricultural land, subsequently. ${ }^{43}$ These values can be explained by the fact that in some irrigated areas, improperly chosen or imprudent irrigation has already led to processes that reduce soil fertility. ${ }^{44}$

In addition, special attention must be paid to drought and its impact on crop production in Hungary. Importantly, the main drought damage prevention tool is not water-based irrigation, but systematic irrigation management, which can intervene in water management processes before drought occurs. ${ }^{45}$ The analysis of the National

\footnotetext{
${ }^{36}$ https://ec.europa.eu/eurostat/tgm/web/table/description.jsp (20. 11. 2019).

${ }^{37} \mathrm{https}: / /$ ec.europa.eu/eurostat/tgm/table.do?tab=table\&init=1\&language=en\&pcode=tai03\&plugin=1 (20. 11. 2019).

${ }^{38} \mathrm{https}$ ://ec.europa.eu/eurostat/tgm/refreshTableAction.do?tab=table\&plugin=1\&pcode=tai03\&language=en (20. 11. 2019).

${ }^{39}$ Magyarország felülvizsgált, 2015. évi Vízgyűjtő-gazdálkodási Terve [Revised National River Basin Management Plan of 2015], 268.

${ }^{40}$ Marosán Ágnes: Statisztikai Jelentések: Öntözésjelentés, 2018. év. NAIK Agrárgazdasági Kutatóintézet, 2019/1, 7.

41 VAHAVA: op. cit., 27.

${ }^{42}$ www.fao.org/nr/water/aquastat/water_use_agr/index.stm (23. 11. 2019).

${ }^{43}$ Marosán (2019): op. cit., 19.

44 Kemény-Lámfalusi-Molnár: op. cit., 16.

45 Ibid., 17.
} 
Adaptation Geo-information System (NAGiS) ${ }^{46}$ suggests that three factors determine the vulnerability of arable crop production to drought in an area. These factors are comprised of the projected variations of the climatic parameters in the area in question, the applied farming methods, as well as the adaptability of that region to the changing climatic conditions. ${ }^{47}$ Their findings of the vulnerability analysis point out that there is a sharp contrast between spring and autumn sown arable crops in terms of their reaction to the predicted changes in climate. Overall, the expected increase in summer drought will only result in a significant average loss of yield for spring sown arable crops, whereas autumn sown arable crops are expected to reach even higher yields at the end of this century. This prediction or explanation is in line with the fact that in case of autumn sown arable crops precipitation in the late winter and during the spring is of strategic importance, and the projections suggest the increase in the average precipitation for the said period. Not to mention that these autumn sown arable crops will not be affected by the increased vulnerability to drought and water scarcity as they will have been harvested by summer. ${ }^{48}$

Hence, nearly three-quarters of Hungary rely on the production of spring sown arable crops, and the situation of these areas is especially vulnerable to the increasing drought. This vulnerability affects primarily the southern part of the country, namely Baranya, Tolna, Bács-Kiskun, as well as Csongrád Counties. The severity of the situation can be illustrated by the fact that failing to change the cultivation practices and in the absence of adaptation investments, expected annual average yields may fall by a third by the end of the century, compared to the values measured at the end of the $20^{\text {th }}$ century. Although the northern and western parts of Hungary generally paint a brighter picture the decline in the average yield can be predicted in all regions. However, it cannot be overemphasised that even if a region or area is not classified as vulnerable it cannot be stated that the average annual yield of spring sown crops will not decrease in the coming decades. Failure to adapt to the changing climate will most likely result in reduced average production even in the regions not classified as vulnerable..$^{49}$

\section{The order of satisfaction of water needs, with special emphasis on irrigation}

Article 15(4) of the Act on Water Management stipulates the order of satisfaction of different forms of water uses. This list is headed by subsistence drinking water, as well as water for public health and disaster relief. This group is followed by water for medical purposes, as well as water for production and service activities directly linked to the supply of population. Under this option, the human right to water approach can be identified, which ensures that satisfying human needs takes priority

\footnotetext{
${ }^{46}$ https://nater.mbfsz.gov.hu/en (29. 11. 2019).

${ }^{47}$ NÉS-2: op. cit., 170.

${ }^{48} \mathrm{lbid}$.

${ }^{49}$ Ibid., 171.
} 
over other uses, and is especially used to challenge the economic and social injustice affecting the most vulnerable groups of the society..$^{50}$ The significance of drinking water in our life can be best illustrated by the fact that without water humans cannot survive for more than a week, whereas without food we may survive for a month. ${ }^{51}$ On the third place of the water hierarchy, water supply for livestock and fish production are ranked, whereas nature protection ${ }^{52}$ can be found in the fourth place. When it comes to fish production, it is obvious that fish require water both in sufficient quantity and quality, and without them they cannot survive at all. As for livestock, the protection of this sector can be supported, among other factors, by the fact that meat consumption is inextricably linked to our diet, and meat production has significant impacts on freshwater resources. Overall, it takes years before animals are slaughtered to produce meat. This life cycle, which is significantly longer than for crops, bears relevance in relation to water footprint.

This relationship was analysed by Hoekstra through the example of the industrial beef production system, where it takes, on average, three years before animals are slaughtered to produce beef (more specifically, about $200 \mathrm{~kg}$ boneless beef). Based on his calculations, in order to produce merely one kilogram of boneless beef, about $6.5 \mathrm{~kg}$ of grain, $36 \mathrm{~kg}$ of roughages, and 155 litres of water are used; however, the said amount of water covers only water for drinking and servicing. Considering that the production of the necessary feed also requires water, notably about 15300 litres of water on average, Hoekstra came to the conclusion that the water footprint of one $\mathrm{kg}$ of beef can add up to 15500 litres of water..$^{53}$ It follows from this analysis that the death of livestock before it would be consumed (utilized for human use) is the loss of tremendous amount of water due to the large amount water embodied in their feed. Lastly, irrigation occupies the penultimate place on the list of water hierarchy, with water for economic and other uses (such as sports, recreation, holiday, bathing, tourism) being last on this list.

Turning our attention to irrigation under the Hungarian law, it is defined by the Government Decree on General rules on activities and facilities for the recovery, protection and repair of waters as "the artificial discharge of non-domestic water, in accordance with the Government Decree on the Exercise of Water Management Power, to supplement natural rainfall in order to increase the efficiency of crop production as well as to maintain lawn that can be irrigated based on legal rules." ${ }^{54}$

\footnotetext{
${ }^{50}$ Klawitter, Simone-Qazzaz, Hadeel: Water as a Human Right: Understanding of Water in the Arab Countries of the Middel East. In: Shuval, Hillel-Dweik, Hassan (eds.): Water Resource in Middle East (Israel-Palestinian Water Issues - From Conflict to Cooperation). Springer, Berlin, Heidelberg, 2007, 284. (doi: 10.1007/9783-540-69509-7_29). See also: UN Committee on Economic, Social and Cultural Rights (CESCR): General Comment No. 15: The Right to Water (Arts. 11 and 12 of the Covenant). 20 January 2003, E/C.12/2002/11. https://www.refworld.org/docid/4538838d11.html (12. 12. 2019).

51 Verschuuren, Jonathan: Recht op water. In: Drupsteen, T. G.-Havekes, H. J. M.-Van Rijswic, H. F. M. W. (eds.): Weids water. Opstellen over waterrecht. Centraal Boekhuis, Sdu Uitgevers, Den Haag, $2006,425$.

52 See Act LIII of 1996 on Nature Protection.

${ }^{53}$ Hoekstra, Arjen Y.: The water footprint of food. In: Förare, Jonas (ed.): Water for Food. The Swedish Research Council for Environment, Agricultural Sciences and Spatial Planning, Stockholm, 2008, 53.

${ }^{54}$ Art. 2(24) of Government Decree 147/2010 (IV. 29.) on the general rules on the activities and installations dedicated for water utilization, protection and water damage management.
} 
Importantly, irrigation necessitates authorisation for irrigation. Based on the Research Institute of Agricultural Economics, in 2016, more than three-quarters of the areas, namely 128823 ha, where authorisation for irrigation were granted, took place on the Great Plain. It is in sharp contrast to Nógrád County where the area for which authorisation for irrigation was granted amounted merely to 66.5 ha. ${ }^{55}$ With regards to water utilized for irrigation in Hungary in 2016, data shows that in the water supply season 68722 ha were actually irrigated, and a total of 73 million $\mathrm{m}^{3}$ of water was used for agricultural irrigation. Not surprisingly, four-fifths of the irrigated areas were located on the Great Plain and as high as 87 per cent of the water was used there as well. ${ }^{56}$ Interestingly, a big discrepancy can be detected between the areas where authorisation for irrigation was granted and where irrigation actually took place, namely merely 53.35 per cent of those areas where authorisations for irrigation were granted were actually irrigated. This percentage, inter alia, encompasses South Transdanubia and North Hungary where more than 60 per cent of the fields were actually irrigated, but Central Transdanubia and West-Transdanubia also form part of this value where the proportion of the irrigated lands was less than 40 per cent. ${ }^{57}$ Data for the year of 2018 suggests although approximately the same size (67 862 ha) of lands were irrigated, the water used for this purpose dramatically increased (119 million $\mathrm{m}^{3}$ ). In spite of this, the proportion of those areas where authorisations for irrigation was granted and where the lands were actually irrigated remained stable (52.8 per cent). ${ }^{58}$

Although interestingly, the definition of 'irrigation' can be found in a government decree, other rules being relevant, more specifically the requirements of water restriction, are regulated by the Act on Water Management. Article 15(5) of the said Act states that "If the restriction of water use becomes necessary, the order of restriction shall be the reverse order of the order of satisfaction specified in paragraph (4)." In other words, as mentioned before, water use for irrigation will be restricted right after economic and other uses. Additionally, KHVM Ministerial Decree 2/1997 (II. 18.) determines the detailed rules on the restrictions concerning water use for agricultural purposes, notably

"the water limit shall be implemented by means of the following steps, which may be applied gradually, in relation to the maximum water jet at the same time as specified in the water permit:

(a) $30 \%$ reduction in water irrigation;

(b) a proportional reduction, as necessary, of all water used for irrigation;

(c) a proportional, but not more than $50 \%$, reduction of the water supply of rice plants;

(d) a proportional reduction of up to $50 \%$ of the water supply of the fishponds (ponds producing fish);

(e) an additional reduction of $20 \%$ of the water supply of the fishponds as set out in point $(d)$.

(6) The water restriction is reversed in reverse order." ${ }^{59}$

${ }^{55}$ Marosán, Ágnes: Statisztikai Jelentések: Öntözésjelentés 2016. év. Agrárgazdasági Kutatóintézet, 2017/1, 4.

${ }^{56}$ Ibid., 5.

${ }^{57}$ Ibid., 6.

${ }^{58}$ Marosán (2019): op. cit., 5-6.

${ }^{59}$ Art. 9 of the KHVM Ministerial Decree 2/1997 (II. 18.) on the Operation of the Agricultural Water Supply Service Provider. 


\section{The water resources levy and the agricultural water supply fee}

This part shall concentrate on the costs in relation to agricultural irrigation, which are determined by the water resources levy and agricultural water supply fee regulated by Article 15/A(1) and Article 15/F(1) of the Act LVII of 1995 on Water Management. However, before doing so, we must refer to Article 15(7) of the Act on Water Management, stating that "Price policy must take into account the principle of recovering the costs of water services, depending on the purpose of the demand for water (distinguishing at least household, industrial, agricultural uses), taking into account the costs of protecting the environment and water resources, the polluter pays principle. When setting prices, account shall be taken of the social, environmental and economic impact of the return." 60

\subsection{The water resources levy}

A water resources levy shall be paid by the water user for the water committed in the authorization for establishment and operation of water rights, or used without authorisation, and by industrial consumers for the water actually consumed. ${ }^{61}$

A water resources levy is paid by the water user after the actual water abstraction. It is calculated by multiplying the following five factors. Firstly, it consists of a basic levy, that is currently 4.50 HUF per $\mathrm{m}^{3}$. Secondly, the water quantity (measured in $\mathrm{m}^{3}$ ) committed to consume or actually consumed by the water user is also taken into account. These factors are supplemented by a multiplier that is equal to 1.0 when the water use is measured by water metering and to 2.0, failing this. The fourth component is the waterbody overload multiplier based on the quantitative status of water bodies in the river basin management plan (1.0 for good or higher status, and 1.2 for lower status). The last determinant is composed of three factors, such as whether the water need is satisfied from surface or groundwater, the water quality, and the type of water use (that is irrigation in the current case). Based on these factors the value may vary between 0.05 and $5.0 .^{62}$

\footnotetext{
${ }^{60}$ See also Article 9 of Directive 2000/60/EC of the European Parliament and of the Council of 23 October 2000 establishing a framework for Community action in the field of water policy (OJ L 327, 22.12.2000, p. 1-73) on recovery of costs for water services; Szilágyi, János Ede: A mezőgazdasági vízjog. In: Szilágyi, János Ede (ed.): Agrárjog: A magyar agrár- és vidékfejlesztési jogi szabályozás lehetőségei a globalizálódó Európai Unióban. Miskolci Egyetemi Kiadó, Miskolc, 2017, 135-136; Dai, Liping: Recovering the Costs of Water Services in the People's Republic of China: Lessons from Article 9 of the European Union Water Framework Directive. Utrecht Law Review, 2012/3, 102-118. (doi: 10.18352/ulr.208); Reese, Moritz: Cost Recovery and Water Pricing in Water Services and Water Uses in Germany. Journal for European Environmental \& Planning Law, 2013/4, 355-377. (doi: 10.1163/18760104-01004005); Unnerstall, Herwig: The Principle of Full Cost Recovery in the EU-Water Framework Directive - Genesis and Content. Journal of Environmental Law, 2007/1, 29-42. (doi: 10.1093/jel/eql038); Lindhout, Petra: Application of the Cost Recovery Principle on Water Services in the Netherlands. Journal for European Environmental \& Planning Law, 2013/4, 309-332. (doi: 10.1163/18760104-01004003); Exposito, Alfonso: Irrigated Agriculture and the Cost Recovery Principle of Water Services: Assessment and Discussion of the Case of the Guadalquivir River Basin (Spain). Water, 2018/10, 1-16. (doi: 10.3390/w10101338).

${ }^{61}$ Art. 15/A(1) of the Act LVII of 1995 on Water Management.

${ }^{62}$ nak.hu/en/tajekoztatasi-szolgaltatas/mezogazdasagi-termeles/96885-ontozesi-celu-vizhasznalat-dijaitmeghatarozo-tenyezok (31. 12. 2019).
} 
Before taking a look at the exemptions under these rules, it is worth noting some advantages of this approach. One of the major benefits of this approach is that the measurement of the water consumption is highly encouraged by entailing a multiplier being twice as much for water consumption without metering. Another benefit is that both the quantitative and qualitative aspects of the water bodies are taken into account, which is relevant for mainly two reasons. Firstly, satisfying water needs for irrigation from surface water is promoted, which can contribute to the protection and preservation of groundwater resources. Secondly, although different water uses claim different water quality, and water for irrigation does not necessitate the highest water quality it does not imply that all kinds of water quality are sufficient for this purpose. In addition, water withdrawals (e.g. for agricultural irrigation) from either surface or groundwater necessarily affect each other in a quantitative sense, but they can have a negative impact on water quality as well ${ }^{63}$ because the quantitative status of water influences the self-purification capacity of water as well.

However, there are exceptions to this general rule, ${ }^{64}$ namely Article $15 / C(1)$ of the Act on Water Management lists some cases when water users shall not have to pay a water resources levy. From our point of view, two cases must be highlighted. Firstly, the water supply fee shall not be paid "after water use for irrigation that does not exceed $400000 \mathrm{~m}^{3}$ per year for water licenses or 400,000 $\mathrm{m}^{3}$ per hectare per year for individual water user after the area irrigated by him." In addition, "The State may derogate from the provision on the obligation to pay a water resources levy under paragraph 1 (I) for reasons of social, environmental and economic effects and geographical and climatic features in favour of the water user." 65

This exemption raises a number of questions. Starting with the potential benefit of this view, first, one can argue that it might reflect farmers' vulnerability to weather conditions and climate compared with other sectors. Furthermore, in spite of the strategic role of agriculture in the EU, including Hungary, the incomes of farmers are considered to be much lower than incomes in non-agricultural sectors. ${ }^{66}$ Secondly, it might refer to the relationship between irrigation, crop production, productivity and food safety, as discussed before. At the same time, countless arguments can be raised against it, including but not limited to the following ones. Firstly, as discussed while analysing the global and national water concerns and challenges, water is a precious resource and it is under pressure due to overexploitation (including agricultural irrigation). Furthermore, water is a vulnerable resource as its renewable capacity is not unlimited, and the negative impacts of climate change are exacerbating the current unfavourable situation. Thereby the protection and preservation

${ }^{63}$ McCaffrey, Stephen C.: The UN Convention on the Law of the Non-Navigational Uses of International Watercourses: Prospects and Pitfalls. In: Salman, Salman M.A.-Boisson de Chazournes, Laurence (eds.): International Watercourses: Enhancing Cooperation and Managing Conflict. The World Bank, Washington, 1997, 18.

${ }^{64}$ See also Szilágyi, János Ede: Aktualitások a mezőgazdasági vízjog köréből: A mezőgazdasági öntözés változó jogi szabályozása. In: Gellén, Klára (ed.): Honori et virtuti: Ünnepi tanulmányok Bobvos Pál 65. születésnapjára. lurisperitus, Szeged, 2017, 433.

${ }^{65}$ Art. 15/C(1a) of the Act LVII of 1995 on Water Management.

${ }^{66}$ See also https://ec.europa.eu/info/food-farming-fisheries/key-policies/common-agricultural-policy/cap-glance_en (13. 11. 2019). 
of water resources should be a priority, however, this approach fails to reflect these concerns. Granting water for free under a certain quantity (even if it is for irrigational use) does not reflect its value. Secondly, in relation to the previous argument it must be added that, in 2016, provided that farmers actually irrigated their land that they used, on average, $1066 \mathrm{~m}^{3}$ water per hectare (this value increased to $1749 \mathrm{~m}^{3}$ per hectare in 2018) was used for agricultural irrigation. This average was only exceeded in the North Great Plain Region, accounting for $1443 \mathrm{~m}^{3}$ per hectare, whereas in other regions the values varied from 425 to $979 \mathrm{~m}^{3}{ }^{67}$ Thirdly, even if we accept the arguments in favour of this approach, namely the vulnerability of crop production to weather conditions as well as the contribution of irrigation to crop productivity (and thus ultimately to food security), some remarks have to be made.

Most importantly, receiving agricultural water supply service is not mandatory. It depends primarily on the willingness and the ability of farmers to afford it. Importantly, it refers not only to the fact as to whether or not the farmer wishes to pay for this service, but whether he wishes to invest in the establishment of an irrigation system. As discussed before, the majority of agricultural lands are rainfed. In other words, receiving agricultural water supply service is voluntary, nonetheless the default rule is that the service has to be paid for. Paying for the service follows from the user-pays principle, which is the "variation of the polluter-pays principle that calls upon the user of a natural resource to bear the cost of running down natural capital." 68 Moreover, this provision does not promote reduced or more efficient water use as under the said quantity does not differentiate between justifiable and unjustifiable, or efficient and inefficient water uses. Additionally, several significant factors are not reflected in this provision, among others, how useful the crop production in question for the society, since not every crop supports food security, thereby not necessarily deserving of special treatment (e.g. the irrigation of tobacco fields). ${ }^{69}$

As regards food security, another important phenomenon to be examined is the question of virtual water. Virtual water is the water embedded in the product, alternatively, water that is used in the production process of agricultural or industrial products. Given the demand for agricultural use of water, the trade of agricultural products and the water they embody have triggered concerns. ${ }^{70}$ Although in theory, the international trade of these products offers an excellent opportunity for countries

\footnotetext{
${ }^{67}$ Marosán (2017): op. cit., 6.; Marosán (2019): op. cit., 6.

68 https://stats.oecd.org/glossary/detail.asp?ID=2827 (10. 11. 2019). Fodor argues that the principle of liability cannot be considered equal with the polluter pays principle and user-pays principle in international and EU environmental law since the latter principles cover a broader category. Fodor, László: Környezetjog. Debreceni Egyetemi Kiadó, Debrecen, 2014, 90.

69 www.madosz.hu/archive/news-view?id=2837 (10. 12. 2019).

${ }^{70}$ Renault, Daniel: Value of Virtual Water in Food: Principles and Virtues. Paper presented to UNESCO-IHE Workshop on Virtual Water Trade, Delft, December 2002. http://www.fao.org/3/ap527e/ap527e.pdf (10. 11. 2019). See also Allan, John Anthony: Virtual Water - the Water, Food, and Trade Nexus. Useful Concept or Misleading Metaphor? Water International, 2003/1, 4-11. (doi: 10.1080/02508060.2003.9724812); Hoekstra, Arjen Y.-Hung, P. Q.: Virtual Water Trade: A Quantification of Virtual Water Flows between Nations in Relation to International Crop Trade. IHE Delft, 2002. https://www.waterfootprint.org/media/downloads/Report11.pdf, 10. (10. 11. 2019); Mekonnen, Mesfin Mergia-Hoekstra, Arjen Y.: National Water Footprint Accounts: The Green, Blue and Grey Water Footprint of Production and Consumption. UNESCO-IHE Institute for Water
} 
with rich water resources since they can benefit from becoming net exporters of these goods and services, whereas water scarce countries can conserve their domestic water resources. ${ }^{71}$ However, in practice, taking into consideration the severity of drought and water scarcity in Hungary as well as producing crops for export, especially if its production is water intensive, it cannot be justified to be exempted from the water resources levy. Quite the contrary, the price of that water should symbolise that by exploiting Hungarian water resources another country and other people (including the farmer or the exporter of the product, but certainly not the public) will benefit from the consumption of these products. As a closing remark concerning Article $15 / C(I)$ reference must be made to the derogation granted by Article $15 / C(1 a)$, namely the State may derogate from the obligation to pay a water resources levy "for reasons of social, environmental and economic effects and geographical and climatic features in favour of the water user." Considering the special reasons indicated in this provision, it must be stressed that these derogations can be justified, however, it is preferable to apply this paragraph instead of Article $15 / \mathrm{C}(\mathrm{I})$ and not in addition to it, and therefore unnecessary as well as inefficient irrigation would be eliminated by lifting the obligation to pay a water resources levy.

Secondly, based on Article $15 / \mathrm{C}(\mathrm{m})$ of the Act on Water Management, ${ }^{72}$ the other case when water users are being exempted from the obligation to pay a water resources levy is "during the extended period of water stress, in accordance with recital 9, after the amount of water used for irrigation, fish farming and rice production." Firstly, it must be noted that similarly to Article 15/C(1) of the Act on Water Management, it leaves no margin of discretion whether the circumstances of the water user justify this treatment or not. What seems certain is that even if the negative impacts of drought are unquestionable, their consequences may affect farmers differently depending on several factors, amongst others, their economic power, the drought resistance of the crop, or whether the land use suits the climate. Given that farmers do not form a homogenous group, their heterogeneity should be reflected in the rules as well. Moreover, in discussing the findings of NAGiS, not only the opportunities in the autumn sown arable crops were pointed out, but also the fact that nearly three-quarter of Hungary relies on the production of spring sown arable crops. As a result, the situation of these areas is especially vulnerable to the increasing drought. For these reasons, it is highly questionable when the increasing frequency and the severity of drought is predicted whether this is the right policy instrument to support farmers. To illustrate this, since Article $15 / C(m)$ of the Act on Water Management entered into force on 1 October 2016, ${ }^{73}$ extended period of water stress was issued for the follow-

Education, Delft, 2011. https://www.waterfootprint.org/media/downloads/Report50-NationalWaterFootprintsVol1.pdf (10. 11. 2019).

${ }^{71}$ Brown Weiss, Edith: The Coming Water Crisis: A Common Concern of Humankind. Transnational Environmental Law, 2012/1, 160-161. (doi: 10.1017/s2047102511000100).

72 This provision was added by Art. 3(1) of the Act XLI of 2016 on the Amendment of the Act LVII of 1995 on Water Management.

${ }^{73}$ Art. 16(2) of the Act XLI of 2016 on the Amendment of the Act LVII of 1995 on Water Management. 
ing periods: from 17 June 2017 to 30 June $2017,{ }^{74}$ from 15 August $^{75}$ to 30 November $2018,^{76}$ and from 1 April $2019^{77}$ to 7 June $2019 .{ }^{78}$ This means that extended period of water stress dominated the irrigation season in the past years.

\subsection{The agricultural water supply fee}

Under Article 15/F(1) of the Act LVII of 1995 on Water Management, "The user of the agricultural water supply service shall pay an agricultural water supply fee to the service provider. The State may assume the water service fee for water use for irrigation, rice production and fish farming as defined in the Government Decree."

One of the key elements of this provision, namely "agricultural water supply" requires further clarification. Annex I to the Water Management Act stipulates the agricultural water supply as the "irrigation of agricultural and forestry land, water supply for ponds and other agricultural water use, and for other purposes related to the agricultural water supply system." 79 So, contrary to the widespread perception, it is a broader phrase than irrigation of agricultural land.

As regards the agricultural water supply fee, it must be stressed that the water supply season runs from 1 March to 31 October in case of irrigation; nonetheless, the operator and the water user may agree at a different time if the directorate agrees. ${ }^{80}$ Importantly, it is not uncommon that agricultural lands are covered with either snow or inland inundation in the spring, including March and early April, which makes agricultural activities impossible to carry out. These phenomena affect primarily the Great Plain. Conversely, the extended period of water stress was issued until 30 November in 2018, which means it lasted a month longer than the water supply season.

The agricultural water supply fee is set out as a two-factor fee consisting of, on the one hand, the basic fee for the availability and the amount of water used, for water supply season and pro rata temporis. ${ }^{81}$ In relation to this basic fee the agricultural water user was obliged to pay 10 per cent of the basic fee from 1 January 2017 to 31 December 2017, and the remaining 90 per cent was covered by the central budget. From 1 January 2018 the proportion paid by the water user was increased by 10 per cent annually with the aim to reach 50 per cent by 1 January 2021, whereas the remaining 50 per cent will be provided by the central budget. ${ }^{82}$ On the other hand,

\footnotetext{
${ }^{74}$ Hivatalos Értesítő, 2017/31.

75 www.katasztrofavedelem.hu/index2.php?pageid=szervezet_hirek\&hirid=5777 (12. 12. 2019).

${ }^{76}$ www.katasztrofavedelem.hu/index2.php?pageid=szervezet_hirek\&hirid=6042 (12. 12. 2019).

77 www.katasztrofavedelem.hu/index2.php?pageid=szervezet_hirek\&hirid=6624 (12. 12. 2019).

${ }^{78} \mathrm{https}$ ://www.nak.hu/tajekoztatasi-szolgaltatas/mezogazdasagi-termeles/99625-veget-ert-a-tartosanvizhianyos-idoszak-2 (12. 12. 2019).

${ }^{79}$ Annex I to the Act LVII of 1995 on Water Management. The same definition was adopted by Art. 1 of Government Decree 115/2014 (IV. 3.) on the Pricing of the Agricultural Water Service Supply.

${ }^{80}$ Art. 6(5) of the KHVM Ministerial Decree 2/1997 (II. 18.) on the Operation of the Agricultural Water Supply Service Provider.

${ }^{81}$ Art. 15/F(3) of the Act LVII of 1995 on Water Management.

${ }^{82}$ Art. 8(2) of the Government Decree 115/2014 (IV. 3.) on the Pricing of the Agricultural Water Service Supply.
} 
the variable water service fee is paid by the agricultural water user as well. From 1 January 2017 to 31 December 2018 an agricultural water user had to pay half of the variable water service fee, however, from 1 January 2019 onwards, the variable water service fee shall be fully paid by the agricultural water user..$^{83}$

\section{Conclusions}

Hungary is in an especially vulnerable situation as 95 per cent of its water resources come from beyond its borders. In addition, the summer precipitation has become more intense and thus less useful whilst the likelihood of drought and water scarcity have increased. Furthermore, under the special climate characterising Hungary, even a slight change or modification in the climate zone may affect the water cycle. The water bodies are sensitive to the spatial and temporal distribution of temperature and precipitation to varying degrees. For all these reasons, the significance of irrigation is unquestionable and unassailable since, on the one hand, it can challenge or reduce the threats caused by the unfavourable climatic or weather conditions, notably drought and water scarcity. At the same time, irrigation can significantly enhance crop productivity if it is prudently carried out.

Nonetheless, based on the revised National River Basin Management Plan adopted in 2015, only 1-2 per cent of agricultural land is irrigated depending on the weather conditions, whereas the proportion of irrigable land is 3.3 per cent. In theory, this could justify encouraging irrigation in Hungary. Irrigation, however, occupies merely the penultimate place in the order of satisfaction of water needs under Article 15(4) of the Act on Water Management since it is preceded by other (competing) water needs. Scoring low on the hierarchy of water needs as well as the potentially good impacts of irrigation on agriculture, however, do not imply that the value of water as an irreplaceable natural resource with limited renewable capacity should not be reflected in the price of the water for irrigation. Quite the contrary, water pricing can be an adequate tool to encourage the efficient and sustainable use of water for irrigation.

Under the current regulations even though both the water resources levy and agricultural water supply fee have to be paid based on Article 15/A(1) and Article $15 / F(1)$ of the Act LVII of 1995 on Water Management, but these provisions allow for the derogation from these obligations at the same time. Allowing derogations from paying for the agricultural irrigation can be acceptable in many cases, including those cases indicated in the current provisions. Although concerns can be raised regarding the uniform application of these derogations without taking into account, among others, the economic power or the financial situation of the farmers, which can vary significantly as farmers form an extremely heterogenous group of the society. Additionally, the derogations leave untouched the question that the contribution of different crops to the food security differ widely. Moreover, exporting water intensive crops and derived products thereof give rise to the problem of virtual water. Last but

${ }^{83}$ Art. 8(1) of the Government Decree 115/2014 (IV. 3.) on the Pricing of the Agricultural Water Service Supply. 
certainly not least, on the one hand, it can be concluded that the application of water efficient technologies should be promoted instead of lifting the obligation to pay for agricultural irrigation. These technologies, including inter alia precision agriculture, attempts to optimize the whole production procedure with special regards to the protection and preservation of water resources. On the other hand, the derogations to the default rule, namely to pay the price of the water for irrigation can be justified, however, these derogations should not be used in a unified way without involving discretion, but several factors should be taken into account before adopting them. 